\title{
Chemical and Volatile Composition of Mango Wines Fermented with Different Saccharomyces cerevisiae Yeast Strains
}

\author{
X. Li ${ }^{1}$, B. Yu ${ }^{2}$, P. Curran², S.-Q. Liu ${ }^{1 *}$ \\ (1) Food Science and Technology Programme, Department of Chemistry, National University of Singapore, 4 Science Drive 4, \\ Singapore 117543 \\ (2) Firmenich Asia Pte Ltd, Tuas, Singapore 638377
}

Submitted for publication: November 2010

Accepted for publication: January 2011

Key words: mango wine, Saccharomyces cerevisiae, volatiles, flavor, aroma, fermentation

\begin{abstract}
The aim of this study was to compare the chemical and volatile composition of mango wines fermented with Saccharomyces cerevisiae var. bayanus EC1118, S. cerevisiae var. chevalieri CICC1028 and S. cerevisiae var. cerevisiae MERIT.ferm. Strains EC1118 and MERIT.ferm showed similar growth patterns but strain CICC1028 grew slightly slowly. The ethanol level reached about $8 \%(\mathrm{v} / \mathrm{v})$ for each mango wine and sugars (glucose, fructose and sucrose) were almost exhausted at the end of fermentation. There were only negligible changes in the concentrations of citric, succinic and tartaric acids, except for malic acid (decreased significantly). Different volatile compounds were produced, which were mainly fatty acids, alcohols and esters. Most volatiles that were present in the juice were consumed to trace amounts. The kinetic changes of volatiles were similar among the three yeasts but the concentrations of some volatiles varied with yeast. Strain MERIT.ferm produced higher amounts of higher alcohols, isoamyl and 2-phenylethyl acetates, whereas strain CICC1028 produced higher amounts of medium-chain fatty acids and ethyl esters of decanoate and dodecanoate. These results suggest that it may be possible to produce mango wines with differential characteristics using different $S$. cerevisiae strains.
\end{abstract}

\section{INTRODUCTION}

Mango (Mangifera indica L.) is commercially one of the most abundant tropical fruits in Southeast Asia, accounting for its large market share of the total mango produced worldwide (Tharanathan et al., 2006). Over 30 different varieties of mango are grown and appreciated for its light to bright yellow colour, its sweet and delicious taste, high nutritive value (high amounts of amino acids, a good source of vitamin A and B6, and low in saturated fat, cholesterol, and sodium), as well as its affordable market price (Spreer et al., 2009; Anonymous, n.d.).

The mango variety chosen for this study was Mangifera indica L. cv. Chok Anan (also called honey mango), which is mostly grown in Malaysia and Thailand. In contrast with most mango varieties, 'Chok Anan' mango has the ability to produce off-season flowering without chemical induction (Spreer et al., 2009). Thus, apart from the main harvest in May, two more harvests follow in June and August. This characteristic enables 'Chok Anan' mangoes to have a large stock each year, which gives it an advantage to be a raw material for further processing, such as mango wine fermentation. Fermentation provides an alternative to selling 'Chok Anan' mango fruits, and further increases its value. Ripe 'Chok Anan' mangoes have a high content of sugar $\left(16.70^{\circ}\right.$ Brix $)$, especially sucrose, glucose and fructose. The sugar content of 'Chok Anan' mango is comparable to that of some grape varieties, making it even more suitable for wine fermentation.
The research on mango wine lacked intensive drive till recently although it started from 1960's. Czyhrinciwk (1966) reported the first study on mango wine production. Onkarayya and Singh (1984) screened twenty varieties of mangoes from India for wine production. Obisanya et al. (1987) studied the fermentation of mango juice into wine using locally isolated Saccharomyces cerevisiae and Schizosaccharomyces species of palm wine and they concluded that Schizosaccharomyces yeasts were suitable for the production of sweet, table mango wine and Saccharomyces yeasts were suitable for the production of dry mango wine with a higher ethanol level. Reddy and Reddy (2005) developed a method of mango juice extraction with pectinase and characterized ethanol and some volatile contents of mango wine. They concluded that the aromatic compounds of mango wine were comparable in concentration to those of grape wine. Reddy and Reddy (2009) published further results of characterizing kinetic changes of higher alcohols in mango wine and concluded that pectinase treatment could enhance the mango juice yield and increase the synthesis of higher alcohols (within a desirable range) as well as mango wine quality. Kumar et al. (2009) used response surface methodology (RSM) for the simultaneous analysis of the effects of fermentation conditions (temperature, $\mathrm{pH}$ and inoculum size) on the chemical characteristics of mango wine.

There is still no complete profiling of volatile compounds of mango wine although a complete profile of volatiles of fresh

*Corresponding author: chmLsq@nus.edu.sg [Tel.:+65 6516 2687; fax: +65 6775 7895] 
mango juice is available (Pino \& Mesa, 2005; Pino et al., 2005). Information is also lacking on the changes in the concentrations of sugars, organic acids and volatile compounds during mango wine fermentation. Further, selection of Saccharomyces yeasts plays a very important part in mango wine flavor modulation, because mango wines with different flavor profiles may result when fermenting the same mango juice with different strains or species of Saccharomyces yeasts. To the best of our knowledge, there are no comprehensive reports on the characteristics of mango wines fermented by different Saccharomyces yeast strains.

The aim of this study was to compare the fermentation performance of three Saccharomyces cerevisiae yeasts (MERIT.ferm, CICC1028, EC1118) and the chemical and volatile composition of the resultant mango wines. The outcome of this study would help select Saccharomyces yeasts for further investigations involving Saccharomyces and nonSaccharomyces to enhance mango wine flavor.

\section{MATERIALS AND METHODS \\ Yeast strains and culture media}

Saccharomyces cerevisiae var. bayanus Lalvin EC1118 (Lallemand Inc, Brooklyn Park, Australia) and Saccharomyces cerevisiae var. chevalieri CICC1028 (China Centre of Industrial Culture Collection, Beijing), and Saccharomyces cerevisiae MERIT.ferm (Chr.-Han., Denmark) were used in this study. Yeast strains were maintained in nutrient broth $(\mathrm{pH}$ $5.0)$ consisting of $2 \%(\mathrm{w} / \mathrm{v})$ glucose, $0.25 \%(\mathrm{w} / \mathrm{v})$ yeast extract, $0.25 \%(\mathrm{w} / \mathrm{v})$ bacteriological peptone, $0.25 \%(\mathrm{w} / \mathrm{v})$ malt extract and were incubated at $25^{\circ} \mathrm{C}$ for up to $48-72$ hours. The yeasts with $20 \%$ glycerol were stored at $-80^{\circ} \mathrm{C}$ before use.

\section{Preparation of mango juice}

Mangoes ('Chok Anan' variety) from Malaysia were purchased from a local market in Singapore and were juiced, centrifuged at 21,000 rpm (41,415×g, Beckman Centrifuge, USA) for $15 \mathrm{~min}$ and stored at $-50^{\circ} \mathrm{C}$ for further use. Pre-culture medium prepared from the mango juice $\left(16.7^{\circ} \mathrm{Brix}\right.$, containing $4.9 \mathrm{~g}$ of fructose, $0.6 \mathrm{~g}$ of glucose and $12.4 \mathrm{~g}$ of sucrose per $100 \mathrm{~mL}$ juice; $\mathrm{pH}$ 4.63) was sterilized through a $0.45 \mu \mathrm{m}$ polyethersulfone filter membrane (Sartorius Stedium Biotech, Germany), inoculated with $1 \%(\mathrm{v} / \mathrm{v})$ of selected yeast strains and incubated for 48 hours until yeasts grew to at least $10^{7} \mathrm{cfu} / \mathrm{mL}$. The mango juice $(\mathrm{pH}$ adjusted to 3.5 with $50 \% \mathrm{w} / \mathrm{v}$ food grade D,L-malic acid from Suntop Ltd, Singapore) used for fermentation was sterilized with 100 ppm of potassium metabisulphite (The Goodlife Homebrew centre, Norfolk, England) and left overnight at $25^{\circ} \mathrm{C}$ before use. Potato dextrose agar (PDA) $(39 \mathrm{~g} / \mathrm{L}$, Oxoid, Basingstoke, Hampshire, England) was used for plating to monitor the growth of the three Saccharomyces yeasts.

\section{Fermentation}

Replicate mango juice fermentations with each Saccharomyces yeast were carried out in $300 \mathrm{~mL}$ sterile Erlenmeyer conical flasks (plugged with cotton wool, then wrapped with aluminum foil) and each flask contained $250 \mathrm{~mL}$ mango juice. The juices were inoculated with $1 \%(\mathrm{v} / \mathrm{v})$ pre-culture of the three Saccharomyces yeasts and fermentation was conducted at $20^{\circ} \mathrm{C}$ statically for 14 days. Samples were taken during fermentation (Day 0, 2, 4, 6, 11 and 14).

\section{Measurement of $\mathrm{pH}$ and Brix}

The total soluble solids (Brix) and $\mathrm{pH}$ were measured at the

TABLE 1

Physicochemical properties, organic acid and sugar concentrations of mango wines before and after fermentation.

\begin{tabular}{|c|c|c|c|c|c|c|}
\hline \multirow[b]{2}{*}{ Yeast strains } & \multicolumn{3}{|c|}{ Day 0} & \multicolumn{3}{|c|}{ Day 14} \\
\hline & MERIT.ferm & CICC1028 & EC1118 & MERIT.ferm & CICC1028 & EC1118 \\
\hline \multicolumn{7}{|c|}{ Physiochemical properties } \\
\hline $\mathrm{pH}$ & $3.52 \pm 0.00^{a}$ & $3.52 \pm 0.00^{a}$ & $3.52 \pm 0.00^{a}$ & $3.54 \pm 0.01^{a}$ & $3.69 \pm 0.01^{b}$ & $3.56 \pm 0.02^{a}$ \\
\hline Brix & $16.61 \pm 0.03^{a}$ & $16.71 \pm 0.02^{a}$ & $16.68 \pm 0.03^{a}$ & $5.36 \pm 0.06^{a}$ & $5.39 \pm 0.02^{a}$ & $5.30 \pm 0.17^{a}$ \\
\hline $\begin{array}{l}\text { Plate count } \\
\left(10^{5} \mathrm{cfu} / \mathrm{mL}\right)\end{array}$ & $5.22 \pm 3.12^{a}$ & $4.64 \pm 2.46^{a}$ & $8.34 \pm 4.99^{b}$ & $8920 \pm 6921^{a}$ & $547 \pm 122^{b}$ & $9455 \pm 3297^{a}$ \\
\hline \multicolumn{7}{|c|}{ Organic acids $(\mathrm{g} / 100 \mathrm{~mL})$} \\
\hline Citric acid & $0.27 \pm 0.04^{a}$ & $0.34 \pm 0.01^{b}$ & $0.23 \pm 0.01^{a}$ & $0.21 \pm 0.03^{a}$ & $0.20 \pm 0.02^{a}$ & $0.24 \pm 0.03^{a}$ \\
\hline Tartaric acid & $0.12 \pm 0.03^{a}$ & $0.09 \pm 0.02^{a}$ & $0.13 \pm 0.04^{a}$ & $0.14 \pm 0.02^{a}$ & $0.11 \pm 0.03^{a}$ & $0.14 \pm 0.01^{a}$ \\
\hline Succinic acid & $0.083 \pm 0.012^{a}$ & $0.075 \pm 0.011^{a}$ & $0.080 \pm 0.007^{a}$ & $0.086 \pm 0.011^{a}$ & $0.081 \pm 0.003^{a}$ & $0.083 \pm 0.002^{a}$ \\
\hline Malic acid & $0.79 \pm 0.03^{a}$ & $0.86 \pm 0.01^{b}$ & $0.745 \pm 0.02^{a}$ & $0.36 \pm 0.05^{a}$ & $0.33 \pm 0.01^{a}$ & $0.41 \pm 0.03^{a}$ \\
\hline \multicolumn{7}{|c|}{ Reducing sugars $(\mathrm{g} / \mathbf{1 0 0 m L})$} \\
\hline Fructose & $4.96 \pm 0.08^{a}$ & $4.87 \pm 0.06^{a}$ & $5.05 \pm 0.07^{a}$ & N.D.* & N.D. & N.D. \\
\hline Glucose & $0.63 \pm 0.02^{a}$ & $0.61 \pm 0.01^{a}$ & $0.62 \pm 0.02^{a}$ & N.D. & N.D. & N.D. \\
\hline Sucrose & $12.25 \pm 0.31^{a}$ & $12.44+0.11^{a}$ & $13.85 \pm 0.07^{b}$ & $0.013 \pm 0.00^{a}$ & $0.013 \pm 0.00^{a}$ & $0.013 \pm 0.00^{a}$ \\
\hline
\end{tabular}

$\overline{a, b, c}$ ANOVA $(\mathrm{n}=4)$ at $95 \%$ confidence level with same letters indicating no significant difference.

*N.D.: not detected. 
indicated time points by using a refractometer (ATAGO, Japan) and a $\mathrm{pH}$ meter (Metrolim, Switzerland), respectively. Samples were analyzed in duplicate for each wine replicate.

\section{Analysis of reducing sugars and organic acids by HPLC}

Wine samples after centrifugation and filtration $(0.2 \mu \mathrm{m})$ were stored at $-50^{\circ} \mathrm{C}$ before analysis. The sugars $(\mathrm{g} / 100 \mathrm{~mL})$ were measured by HPLC (Shimadzu HPLC, Class-VP software version 6.1) according to the method of Chávez-Servín et al. (2004), using a carbohydrate ES column (Prevail, 150×4.6 $\mathrm{mm})$. The column was eluted at $25^{\circ} \mathrm{C}$ with a degassed mobile phase containing a mixture of acetonitrile and water (78:22) at a flow rate of $0.5 \mathrm{~mL} / \mathrm{min}$ (isocratic mode). All the compounds were detected with an evaporative light scattering detector. Samples were analyzed in duplicate for each wine replicate $(n=4)$. The identification and quantification of sugars were achieved by using retention time and standard curves of pure sugar compounds (Sigma-Aldrich, St. Louis, MO, USA).

The organic acids (tartaric, citric, succinic and malic acids) were determined by HPLC (Shimadzu) using a Supelcogel C-610H column (Supelco, Bellefonte, PA, USA) connected to a photodiode array detector. The column was eluted at $40^{\circ} \mathrm{C}$ with a degassed aqueous mobile phase containing $0.1 \%$ sulphuric acid at a flow rate of $0.4 \mathrm{~mL} / \mathrm{min}$ (isocratic mode). Samples were analyzed in duplicate for each wine replicate. The identification and quantification of compounds were carried out by using retention time, UV spectrum $(210 \mathrm{~nm})$ and standard curves of pure organic acid compounds (Sigma-Aldrich, St. Louis, MO, USA).

\section{Analysis of volatile compounds by HS-SPME-GC-MS/FID}

The method was based on that described elsewhere (Lee et al., 2010a; Trinh et al., 2010) with some modifications. Volatile compounds of fresh juice and final fermented juice (samples after 14-day fermentation) were measured using headspace (HS) solid-phase microextraction (SPME) method coupled with gas chromatography (GC)-mass spectrometer (MS) and flame ionization detector (FID) (HS-SPME-GC-MS FID). CarboxenPDMS fibre $(85 \mu \mathrm{m})$ (Supelco, Sigma-Aldrich, Barcelona, Spain) was used for extraction. Five millilitres of mango wine sample was extracted by HS-SPME at $60^{\circ} \mathrm{C}$ for 40 min under $250 \mathrm{rpm}$ agitation. The fibre was desorbed at $250^{\circ} \mathrm{C}$ for $3 \mathrm{~min}$ and the sample was injected into Agilent 7890A GC (Santa Clara, CA, USA), which was coupled to FID and Agilent 5975C triple-axis MS. Separation was achieved using capillary column (Agilent DB-FFAP) of $60 \mathrm{~m} \times 0.25 \mathrm{~mm}$ I.D. coated with $0.25 \mu \mathrm{m}$ film thickness of polyethylene glycol modified with nitroterephthalic acid. The carrier gas was helium. The operation conditions were as follows: the oven temperature was programmed from $50^{\circ} \mathrm{C}$ for $5 \mathrm{~min}$, then increased with $5^{\circ} \mathrm{C} / \mathrm{min}$ until $230^{\circ} \mathrm{C}$, and kept at $230^{\circ} \mathrm{C}$ for $30 \mathrm{~min}$. The FID temperature was set at $250^{\circ} \mathrm{C}$, and the MSD was operated in the electron impact mode at $70 \mathrm{eV}$. The volatile compounds were identified by using Wiley mass spectrum library and comparison of linear retention index (LRI) of each volatile with the LRI in other reports (Tairu et al., 1999; Lee et al., 2010a; Trinh et al., 2010). LRI was determined by using a series of alkanes (C5-C40) run under the same HS-SPME-GC-MS/FID condition as sample analysis and it was calculated according to the equation:

$$
\mathrm{LRI}=100 \times\left[\left(\mathrm{t}_{\mathrm{i}}-\mathrm{t}_{\mathrm{z}}\right) /\left(\mathrm{t}_{\mathrm{z}+1}-\mathrm{t}_{\mathrm{z}}\right)+\mathrm{z}\right]
$$

where $\mathrm{z}$ is the number of carbon atoms of the $\mathrm{n}$-alkane eluting before and $(z+1)$ is the number of carbon atoms of the n-alkane eluting after the peak of interest. FID peak area was used to calculate RPA of each volatile and it can help semi-quantitatively compare the relative difference of each volatile, minor or major, among three wines. The final fermented samples ("Day 14" sample) were analyzed in duplicate for each wine replicate, but fresh mango juice was analyzed in triplicate.

Major volatiles (high RPA in the FID chromatogram; which are important for wine quality) were quantified using individual external standards dissolved in $10 \% \mathrm{v} / \mathrm{v}$ mango juice diluted with water, except for ethanol dissolved in $100 \% \mathrm{v} / \mathrm{v}$ mango juice (Lee et al., 2010b; Trinh et al., 2010). Good linearity was obtained for all standard curves $\left(\mathrm{R}^{2}>0.97\right)$. The kinetic changes of the concentration of these compounds were monitored throughout the whole fermentation. The HS-SPME-GC-MS FID condition used for quantification is the same as the abovementioned conditions. Samples were analyzed in duplicate for each wine replicate $(n=4)$. Thereafter, odor activity values (OAVs) of these quantified volatiles were calculated according to their established threshold levels (in synthetic wine base) in other published reports (Guth, 1997; Bartowsky \& Pretorius, 2008).

\section{Statistical analysis}

ANOVA $(P<0.05)$ was used to determine the significance of the difference of each chemical or volatile factor among three fermentations.

\section{RESULTS AND DISCUSSION}

\section{Brix, pH and yeast growth}

The mango juice had a soluble solids content of $16.7^{\circ}$ Brix. The three strains of $S$. cerevisiae yeasts had similar fermentation characteristics in terms of Brix change, $\mathrm{pH}$ changes and yeast growth. The $\mathrm{pH}$ values fluctuated from 3.50 to 3.69 and Brix values were reduced to $5.3^{\circ}-5.4^{\circ}$ for all three mango wines during the fermentation. The cell populations of all three yeasts increased from the initial $5 \times 10^{5} \mathrm{cfu} / \mathrm{mL}$ (MERIT.ferm), $4.5 \times 10^{5}$ $\mathrm{cfu} / \mathrm{mL}(\mathrm{CICC} 1028), 8.5 \times 10^{5} \mathrm{cfu} / \mathrm{mL}(\mathrm{EC} 1118)$ and reached their respective maximum on day 14, where strain EC1118 showed the highest growth at $9.46 \times 10^{8} \mathrm{cfu} / \mathrm{mL}$, followed by strain MERIT.ferm at $8.92 \times 10^{8} \mathrm{cfu} / \mathrm{mL}$ and strain CICC1028 at $5.47 \times 10^{7} \mathrm{cfu} / \mathrm{mL}$ (Table 1 ). Based on the plate counts, it seemed that strain CICC1028 was less stress-tolerant of stress than strains EC1118 and MERIT.ferm because its cell count was about 10 times less.

\section{Changes of sugars and organic acids}

Fructose, glucose and sucrose were the three reducing sugars detected in the fresh mango juice. The sugar contents in the juices inoculated with the three $S$. cerevisiae displayed rapid reduction during fermentation. Strain CICC1028 showed the fastest consumption of fructose and glucose among the three yeasts (data not shown). In addition, the three strains showed a similar pattern of sucrose utilization. At day 14, 
TABLE 2

Major volatile compounds (GC-FID peak area $\times 10^{6}$ ) and their relative peak areas (RPA) in fresh 'Chok Anan' mango juice.

\begin{tabular}{|c|c|c|c|c|c|c|}
\hline Groups & $\mathrm{LRI}^{(1)}$ & CAS No. ${ }^{(2)}$ & Compounds & Peak area & RPA (\%) & $\begin{array}{c}\text { Aroma descriptors of pure } \\
\text { compounds }^{(3)}\end{array}$ \\
\hline \multirow[t]{17}{*}{ Monoterpenes } & 1088 & $007785-70-8$ & Alpha-pinene & $10.86 \pm 1.23$ & 0.87 & Resinous, pine-like \\
\hline & 1127 & $000079-92-5$ & Camphene & $1.55 \pm 0.27$ & 0.12 & $\begin{array}{l}\text { Harsh, camphoraceous, } \\
\text { coniferous }\end{array}$ \\
\hline & 1206 & 013466-78-9 & Delta-3-carene & $78.91 \pm 7.28$ & 6.36 & Harsh, terpene-like, coniferous \\
\hline & 1211 & $000471-84-1$ & Alpha-fenchene & $3.52 \pm 0.21$ & 0.28 & Camphor-like \\
\hline & 1219 & $002867-05-2$ & Alpha-thujene & $15.87 \pm 1.05$ & 1.28 & Woody, green herb \\
\hline & 1226 & $018172-67-3$ & Beta-pinene & $1.08 \pm 0.36$ & 0.09 & Sharp, terpenic, conifers \\
\hline & 1235 & 000099-86-5 & Alpha-terpinene & $71.43 \pm 5.33$ & 5.75 & Sharp, terpenic, lemon \\
\hline & 1254 & $095327-98-3$ & Limonene & $59.42 \pm 4.28$ & 4.79 & Citric, terpenic, orange note \\
\hline & 1265 & $000555-10-2$ & Beta-phellandrene & $5.71 \pm 0.87$ & 0.46 & Mint, terpene-like \\
\hline & 1268 & $000508-32-7$ & Tricyclene & $5.64 \pm 0.79$ & 0.45 & - \\
\hline & 1290 & $027400-71-1$ & Cis-ocimene & $2.28 \pm 0.33$ & 0.18 & Citrus, green, lime \\
\hline & 1305 & $000099-85-4$ & Gamma-terpinene & $40.2 \pm 5.22$ & 3.24 & Fatty, terpenic, lime \\
\hline & 1339 & 000099-87-6 & p-Cymene & $12.56 \pm 2.78$ & 1.01 & Citrus, terpenic, woody \\
\hline & 1343 & $000535-77-3$ & $m$-Cymene & $123.33 \pm 10.25$ & 9.94 & Citrus, terpenic, woody \\
\hline & 1352 & $000586-62-9$ & Alpha-terpinolene & $560.55 \pm 20.27$ & 45.16 & Citrus, lime, pine \\
\hline & 1450 & $000673-84-7$ & Allo-ocimene & $1.87 \pm 0.52$ & 0.15 & Floral, nutty, peppery \\
\hline & 1529 & 001195-32-0 & p-Cymenene & $101.87 \pm 7.22$ & 8.21 & Citrus, pine-like \\
\hline Subtotal & & & & 1096.65 & 88.35 & \\
\hline \multirow[t]{4}{*}{ Sesquiterpenes } & 1695 & $000087-44-5$ & Trans-Caryophyllene & $0.38 \pm 0.07$ & 0.03 & Woody, clove note \\
\hline & 1778 & $028624-23-9$ & Delta-Selinene & $0.42 \pm 0.13$ & 0.03 & - \\
\hline & 1826 & 004630-07-3 & Valencene & $0.19 \pm 0.02$ & 0.02 & Orange, citrus, woody \\
\hline & 1829 & 017066-67-0 & Beta-selinene & $2.52 \pm 0.88$ & 0.20 & - \\
\hline Subtotal & & & & 3.51 & 0.28 & \\
\hline \multirow[t]{7}{*}{ Alcohols } & 1032 & $000064-17-5$ & Ethanol & $7.1 \pm 1.23$ & 0.57 & Alcoholic \\
\hline & 1476 & 000928-96-1 & Cis-3-hexenol & $87.69 \pm 7.99$ & 7.06 & Green, leafy \\
\hline & 1578 & 000704-76-7 & 2-Ethyl-1-hexanol & $2.55 \pm 0.92$ & 0.21 & Oily, rose, sweet \\
\hline & 1794 & 000470-08-6 & Beta-fenchol & $0.18 \pm 0.03$ & 0.01 & Camphor-like, woody \\
\hline & 1808 & $000464-43-7$ & Endo-borneol & $0.16 \pm 0.08$ & 0.01 & Camphor-like, woody \\
\hline & 1999 & $000078-70-6$ & Linalool & $0.19 \pm 0.03$ & 0.02 & $\begin{array}{l}\text { Fresh floral, herbal, rosewood, } \\
\text { petitgrain }\end{array}$ \\
\hline & 2035 & $000060-12-8$ & 2-Phenylethyl alcohol & $0.35 \pm 0.12$ & 0.03 & Rose, honey, floral \\
\hline Subtotal & & & & 98.22 & 7.91 & \\
\hline \multirow[t]{8}{*}{ Esters } & 1284 & $000109-21-7$ & Butyl butanoate & $2.14 \pm 0.21$ & 0.17 & Fruity, pineapple, sweet \\
\hline & 1396 & $003681-71-8$ & 3-Hexenyl acetate & $10.71 \pm 1.44$ & 0.86 & $\begin{array}{l}\text { Sharp fruity-green, sweet, } \\
\text { green banana-like }\end{array}$ \\
\hline & 1410 & 002497-18-9 & $\begin{array}{l}\text { Trans-2-hexenyl } \\
\text { acetate }\end{array}$ & $0.24 \pm 0.01$ & 0.02 & Fruity, green, leafy \\
\hline & 1440 & 000629-33-4 & Hexyl formate & $5.31 \pm 0.66$ & 0.43 & Green, ethereal, fruity \\
\hline & 1466 & $033467-74-2$ & $\begin{array}{l}\text { Cis-3-hexenyl } \\
\text { propionate }\end{array}$ & $0.52 \pm 0.04$ & 0.04 & Fresh, fruity, green \\
\hline & 1546 & 016491-36-4 & $\begin{array}{l}\text { Cis-3-hexenyl } \\
\text { isobutyrate }\end{array}$ & $1.20 \pm 0.33$ & 0.10 & Apple, fruity, green \\
\hline & 1700 & $065405-80-3$ & $\begin{array}{l}\text { (Z)-3-hexenyl } \\
\text { (E)-2-butenoate }\end{array}$ & $0.17 \pm 0.00$ & 0.01 & Green, sweet, fruity \\
\hline & 1948 & 000110-38-3 & Ethyl dodecanoate & $0.32 \pm 0.03$ & 0.03 & Sweet, Wine, Brandy \\
\hline Subtotal & & & & 20.61 & 1.66 & \\
\hline
\end{tabular}


TABLE 2 (CONTINUED)

Major volatile compounds (GC-FID peak area $\times 10^{6}$ ) and their relative peak areas (RPA) in fresh 'Chok Anan' mango juice.

\begin{tabular}{|c|c|c|c|c|c|c|}
\hline Groups & $\mathrm{LRI}^{(1)}$ & CAS No. ${ }^{(2)}$ & Compounds & Peak area & RPA (\%) & $\begin{array}{c}\text { Aroma descriptors of pure } \\
\text { compounds }^{(3)}\end{array}$ \\
\hline \multirow[t]{3}{*}{ Acids } & 1549 & 000064-19-7 & Acetic acid & $0.62 \pm 0.03$ & 0.05 & Vinegar-like \\
\hline & 1728 & $000067-43-6$ & Butanoic acid & $1.35 \pm 0.09$ & 0.11 & Cheesy, rancid butter \\
\hline & 2171 & 000124-07-2 & Octanoic acid & $0.24 \pm 0.01$ & 0.02 & Acidic, fatty, soapy \\
\hline Subtotal & & & & 2.21 & 0.18 & \\
\hline \multirow[t]{8}{*}{ Aldehydes } & 1152 & $000066-25-1$ & Hexanal & $0.79 \pm 0.05$ & 0.06 & Fatty, green, grassy \\
\hline & 1310 & $006728-26-3$ & Trans-2-hexenal & $2.95 \pm 0.21$ & 0.24 & Apple, strawberry \\
\hline & 1500 & $000142-83-6$ & $\begin{array}{l}\text { Trans, trans-2,4- } \\
\text { hexadienal }\end{array}$ & $0.60 \pm 0.04$ & 0.05 & Fatty, sweet, green \\
\hline & 1572 & 000098-01-1 & Furfural & $0.19 \pm 0.01$ & 0.02 & Almond, caramel, sweet \\
\hline & 1633 & $000100-52-7$ & Benzaldehyde & $0.10 \pm 0.00$ & 0.01 & Bitter almond \\
\hline & 1723 & $000432-25-7$ & Beta-cyclocitral & $0.17 \pm 0.02$ & 0.01 & Fruity, green, minty \\
\hline & 1731 & $000620-23-5$ & $\begin{array}{l}\text { 3-Methyl- } \\
\text { benzaldehyde }\end{array}$ & $0.28 \pm 0.04$ & 0.02 & Sweet fruity cherry \\
\hline & 1771 & 000104-87-0 & $p$-Tolualdehyde & $2.69 \pm 0.76$ & 0.22 & $\begin{array}{l}\text { Sweet aromatic, bitter almond } \\
\text { and cherry notes }\end{array}$ \\
\hline Subtotal & & & & 7.77 & 0.63 & \\
\hline \multirow[t]{6}{*}{ Ketones } & 1281 & 006137-06-0 & $\begin{array}{l}\text { 4-Methyl-2- } \\
\text { heptanone }\end{array}$ & $0.65 \pm 0.02$ & 0.05 & - \\
\hline & 1701 & $004077-47-8$ & Mesifurane & $0.16 \pm 0.04$ & 0.01 & - \\
\hline & 1758 & $000096-48-0$ & $\begin{array}{l}\text { Dihydro-2(3H)- } \\
\text { furanone }\end{array}$ & $0.53 \pm 0.04$ & 0.04 & - \\
\hline & 1834 & 000695-06-7 & $\begin{array}{l}\text { 5-Ethyldihydro- } \\
\text { 2(3H)-furanone }\end{array}$ & $0.50 \pm 0.11$ & 0.04 & Herbaceous, waxy, creamy note \\
\hline & 1938 & 023696-85-7 & Beta-damascenone & $1.31 \pm 0.23$ & 0.11 & Sweet, floral, fruity \\
\hline & 2051 & 000104-50-7 & Gamma-octalactone & $0.97 \pm 0.09$ & 0.08 & Coconut \\
\hline Subtotal & & & & 4.12 & 0.33 & \\
\hline \multirow[t]{2}{*}{ Furan } & 1044 & 003208-16-0 & 2-Ethyl furan & $4.95 \pm 0.53$ & 0.40 & Ethereal rum, cocoa note \\
\hline & 1514 & $001746-11-8$ & $\begin{array}{l}\text { 2,3-Dihydro-2- } \\
\text { methyl-benzofuran }\end{array}$ & $1.66 \pm 0.02$ & 0.13 & - \\
\hline Subtotal & & & & 6.61 & 0.53 & \\
\hline \multirow[t]{3}{*}{ Ether } & 1434 & 016409-43-1 & Cis-rose oxide & $0.81 \pm 0.09$ & 0.07 & Rose, geranium \\
\hline & 1537 & 068780-91-6 & Trans-linalool oxide & $0.42 \pm 0.03$ & 0.03 & Sweet, lemon, cineol \\
\hline & 1563 & 001786-08-9 & Nerol oxide & $0.94 \pm 0.08$ & 0.08 & $\begin{array}{l}\text { Floral, orange blossom, green, } \\
\text { sweet }\end{array}$ \\
\hline Subtotal & & & & 2.17 & 0.17 & \\
\hline Total & & & & 1241.87 & 100 & \\
\hline
\end{tabular}

(1) LRI of all the relative tables was determined on the DB-FFAP column, relative to $\mathrm{C}_{5}-\mathrm{C}_{40}$ hydrocarbons.

${ }^{(2)}$ CAS.number of all the relative tables was obtained from Wiley MS library.

${ }^{(3)}$ Aroma descriptors obtained from http://www.thegoodscentscompany.com.

sugar consumption was almost complete in the fermentation process, with only about $0.013 \mathrm{~g} / 100 \mathrm{~mL}$ of sucrose left in day 14 samples (Table 1). Compared with the study of Reddy and Reddy (2009), the residual sugar level in our study was even lower from similar starting concentrations, which might be due to different mango cultivars or yeasts used.

Organic acids showed different changes during fermentation (Table 1). Citric acid in all three mango wines stayed almost constant at $0.20-0.27 \mathrm{~g} / 100 \mathrm{~mL}$ (except for strain CICC1028). In addition, tartaric and succinic acids did not change significantly for all three wines at $0.1 \mathrm{~g} / 100 \mathrm{~mL}$ and $0.08 \mathrm{~g} / 100 \mathrm{~mL}$, respectively. D,L-malic acid was spiked in mango juice at the beginning of the fermentation to adjust $\mathrm{pH}$ to 3.5. Therefore, the total malic acid increased from 0.3 $\mathrm{g} / 100 \mathrm{~mL}$ to about $0.8 \mathrm{~g} / 100 \mathrm{~mL}$ after spiking. The total malic acid decreased by day 6 and remained constant afterwards (data for day 6 not shown). The decrease in total malic acid before day 6 might not be due to malic acid catabolism because $S$. cererevisiae is generally not capable of metabolizing malic acid. However, D- and L-malic acid molecules could enter the cells of $S$. cerevisiae strains by passive diffusion (Coloretti et al., 2002). Furthermore, the decrease in malic acid was not 

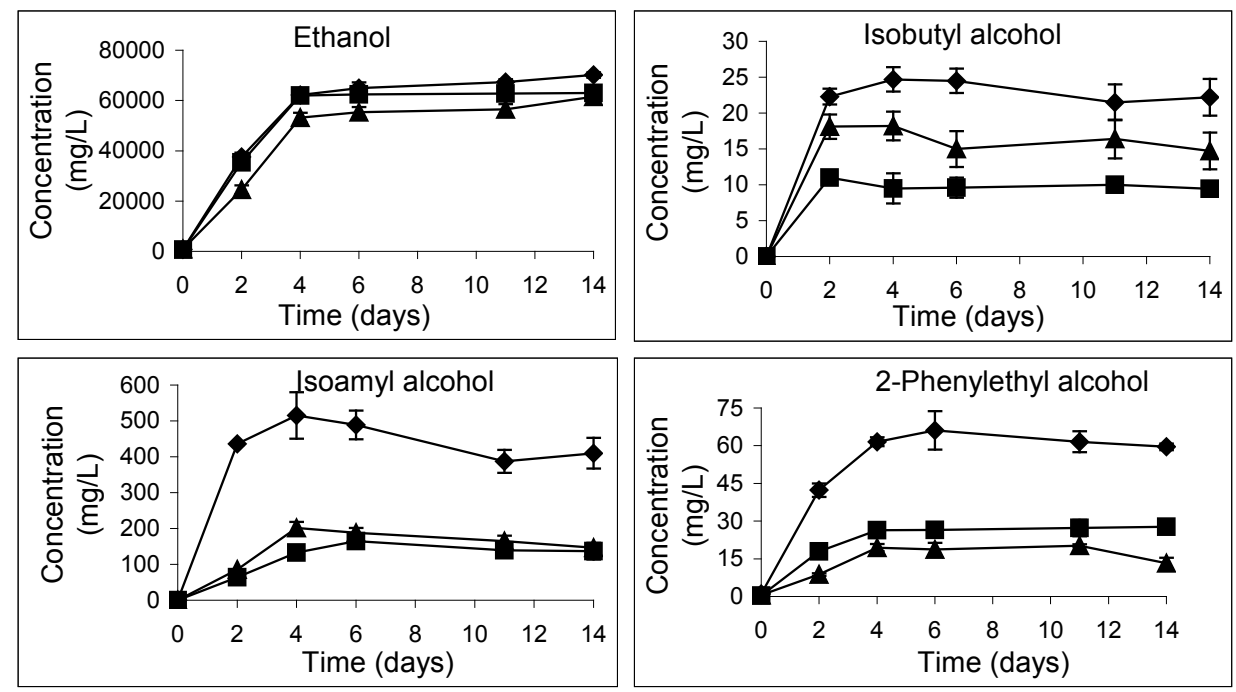

FIGURE 1

Changes of alcohols in mango wines during fermentation by S. cerevisiae MERIT.ferm ( ), S. chevalieri CICC-1028 ( $\Delta$ ) and S. bayanus EC-1118 (๘).

likely due to malolactic fermentation, given the lack of lactic acid (none detected) and the addition of $100 \mathrm{ppm}$ of potassium metabisulphite to the juice.

\section{Volatile compounds in fresh mango juice}

The isomers of monoterpenes $\left(\mathrm{C}_{10} \mathrm{H}_{16}\right)$ and sequiterpenes $\left(\mathrm{C}_{15} \mathrm{H}_{24}\right)$ dominated the major volatiles of fresh mango juice, and their FID RPA reached $89 \%$ (Table 2). Further, several esters, acids, furanones, aldehydes and ketones were also important for the aroma of fresh 'Chok Anan' mangoes, such as butyl butanoate, 3-hexenyl acetate, hexyl formate, rose oxide, cis-3-hexenol, butanoic acid, beta-damascenone and trans2-hexenal. Most of the volatiles identified in the mango juice were similar to those reported elsewhere (Pino et al., 2005; Pino $\&$ Mesa, 2005). However, most of these volatiles (e.g. terpene hydrocarbons) were metabolized, although a few of them were still detectable after fermentation (e.g. beta-damascenone). The result is in contrast with some previous reports which claimed that fermentation would not affect the concentration of terpenes (Rapp, 1988; Ong \& Acree, 1999; Alves, 2010). Nonetheless, Zoecklein et al. (1997) showed that some Saccharomyces strains would cause the decrease of terpenes, which is in agreement with our findings. The reason(s) for this discrepancy is not known and should be further investigated.

Volatile composition of mango wines after 14-day fermentation and kinetic changes of major volatiles

During the 14-day fermentation of mango juice, a number of volatiles were produced: 4 fatty acids, 5 alcohols, 23 esters, 5 ketones, 3 aldehydes and 1 sulfur compound [dihydro-2-methyl$3(2 \mathrm{H})$-thiophenone] (Table 3 ). The volatile composition of the three mango wines is almost the same, but the concentration of each volatile may be different. To compare the volatile compounds in the three wines, FID peak area and RPA were used and they can semi-quantitatively represent the concentration of different volatiles (Alves et al., 2010; Lee et al., 2010ab; Trinh et al., 2010). For further accuracy, 12 major volatile compounds, which are generally considered as important factors influencing fruit or grape wine quality (Gürbüz et al., 2006; Alves et al., 2010; Lee et al., 2010ab; Trinh et al., 2010), were quantified with external standards (Table 4).

Alcohols are quantitatively the largest group of all the volatiles, with RPA accounting for more than $60 \%$ for all three wines. In Tables 3 and 4, strain MERIT.ferm consistently produced the highest amounts of all major alcohols (ethanol, isobutyl alcohol, isoamyl alcohol and 2-phenylethyl alcohol). The kinetic changes of these major alcohols are consistent: constant after day 4 of fermentation (Fig. 1). Ethanol concentrations were $8.8 \%, 7.8 \%, 8.1 \%(\mathrm{v} / \mathrm{v})$ for strains MERIT. ferm, CICC1028 and EC1118, respectively. The concentration of isoamyl alcohol was much higher than that of isobutyl and 2-phenylethyl alcohols in all three mango wines, with strain MERIT.ferm producing $409.9 \mathrm{mg} / \mathrm{L}$, CICC1028 producing $146.4 \mathrm{mg} / \mathrm{L}$ and EC1118 producing $136.9 \mathrm{mg} / \mathrm{L}$ (Table 4). In addition, MERIT.ferm produced $22.2 \mathrm{mg} / \mathrm{L}$ of isobutyl alcohol and $59.6 \mathrm{mg} / \mathrm{L}$ of 2-phenylethyl alcohol, CICC1028 produced 9.4 and $24.5 \mathrm{mg} / \mathrm{L}$, EC1118 produced 14.7 and $27.7 \mathrm{mg} / \mathrm{L}$, respectively (Table 4). The levels of the three branched-chain higher alcohols except for isobutyl alcohol were higher than their published threshold levels for all three mango wines (Table 4).

These branched-chain higher alcohols are important components of the wine bouquet, which are released into the medium as secondary products of the metabolism of yeasts (Noguerol-Pato et al., 2009). They are formed by transamination or deamination of the corresponding amino acids through the Ehrlich pathway (Myers et al., 1970; Dickinson et al., 1998; Etschmann et al., 2002). The keto-acids formed from this pathway are decarboxylated to aldehydes and further reduced to branched-chain higher alcohols. Rapp and Mandery (1987) reported that the concentration of total higher alcohols in wine is in the range of $80-540 \mathrm{mg} / \mathrm{L}$. High quantities of these compounds are considered to be undesirable in table wines, and concentrations below $350 \mathrm{mg} / \mathrm{L}$ can be considered 

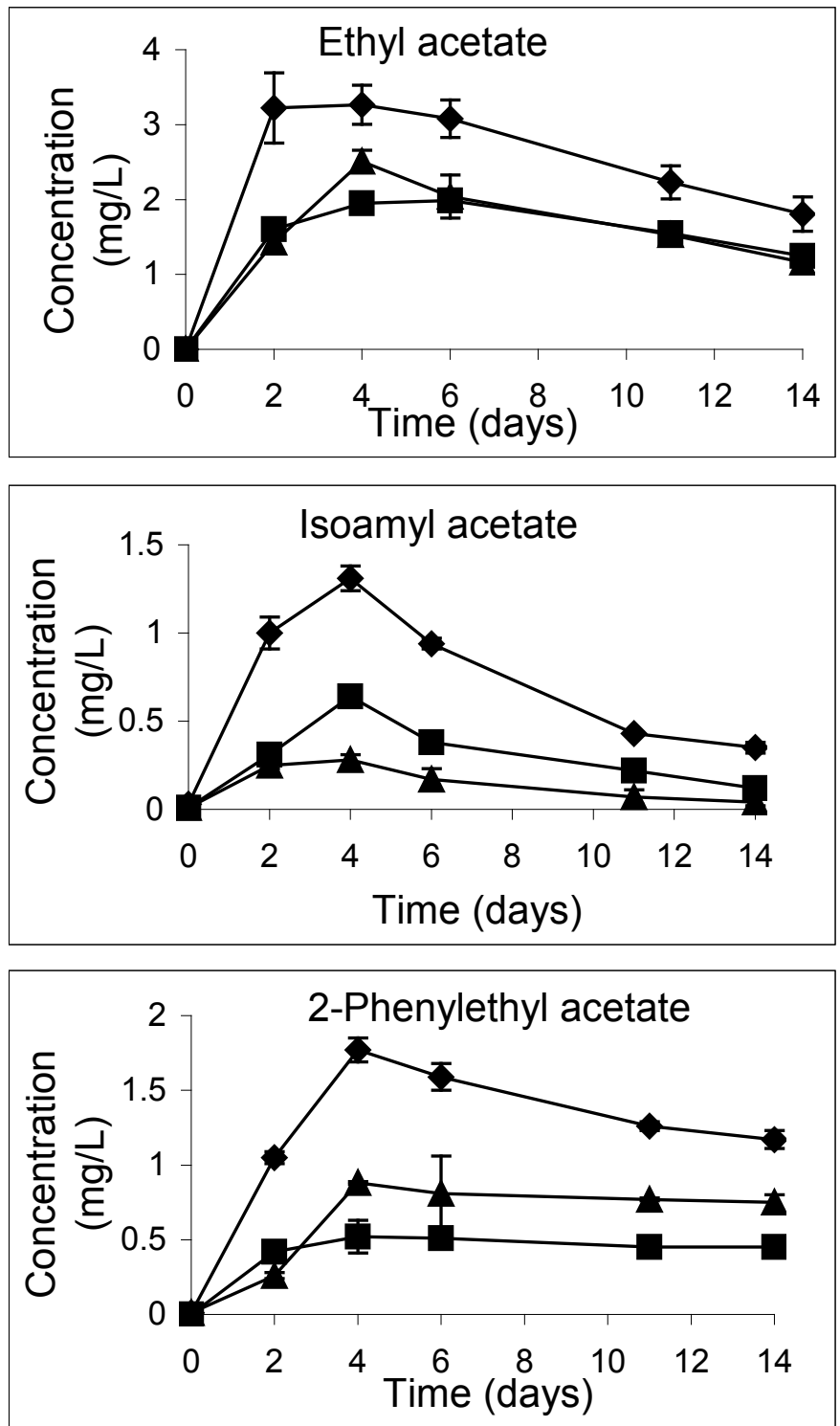

FIGURE 2

Changes of acetate esters in mango wines during fermentation by $S$. cerevisiae MERIT.ferm ( ), S. chevalieri CICC-1028 ( $\mathbf{\Delta})$ and S. bayanus EC-1118 (ם).

to contribute to the positive aromas of wines (Rapp \& Mandery, 1986). Obviously, the higher alcohols (especially isoamyl alcohol) level of strain MERIT.ferm-fermented wine are in the "undesirable" range, however, they might be used as main precursors of branched-chain aromatic esters (e.g. isoamyl acetate, 2-phenylethyl acetate) and these esters can provide enhanced fruity and floral aroma for wine. Yilmaztekin et al. (2009) reported Williopsis saturnus is able to convert isoamyl alcohol into isoamyl acetate. If strain Merit.ferm could coferment mango juice with ester-producing Williopsis yeasts, it may probably promote the formation of branched-chain and aromatic esters.

Some quantitatively minor alcohols were also identified in mango wines, such as cis-3-hexenol, 1-octanol and citronellol (Table 3). They may impart sensory attributes such as "fruity" or "floral" flavor to mango wines. For example, citronellol is a
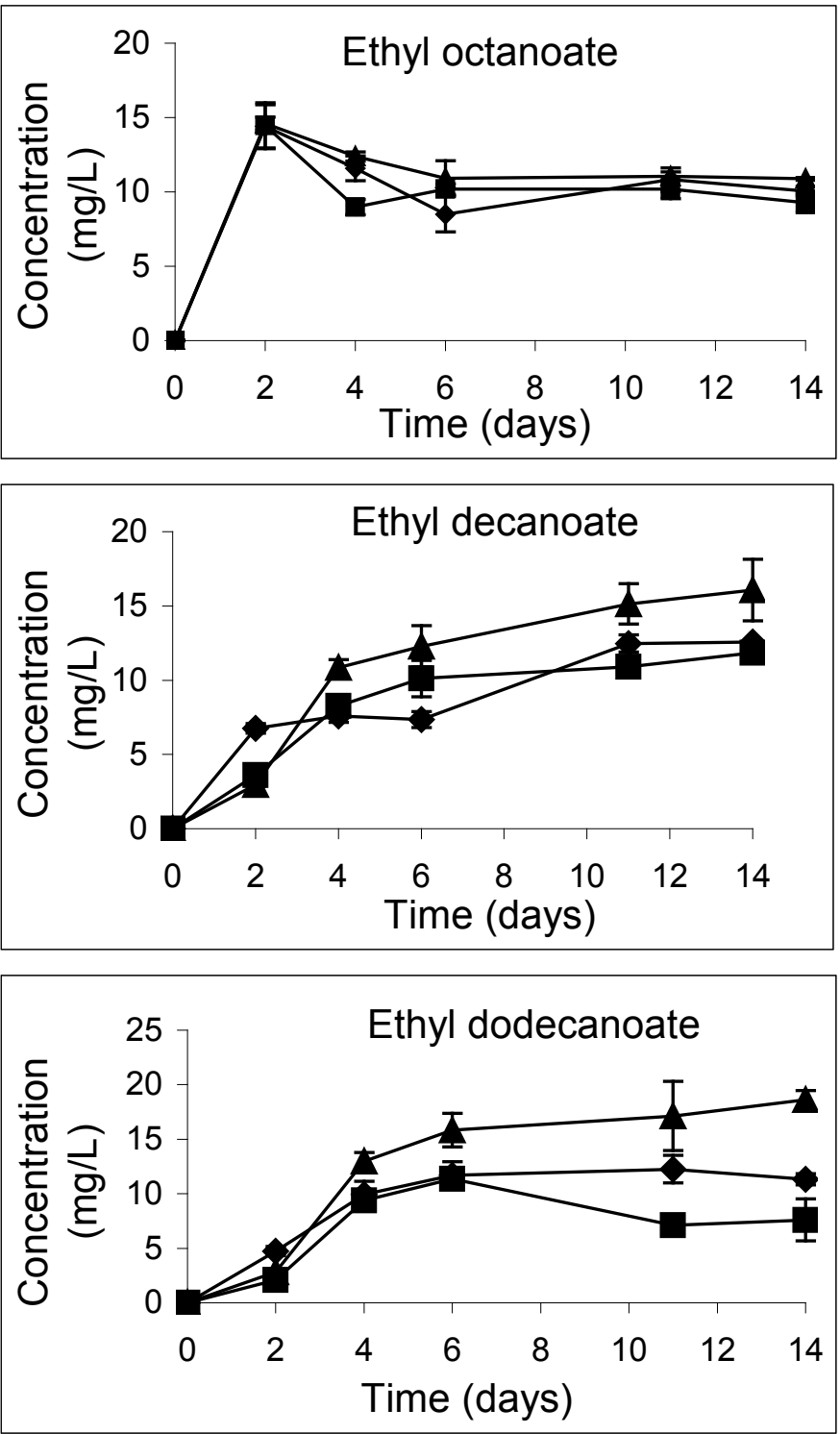

FIGURE 3

Changes of ethyl esters in mango wines during fermentation by $S$. cerevisiae MERIT.ferm ( ), S. chevalieri CICC-1028 ( $\mathbf{\Delta})$ and S. bayanus EC-1118 (ם).

fragrant and flavourful compound that is of great interest to the wine making industry because it can be used to synthesize other aromatic compounds, e.g. rose oxide (lychee flavour) (Alves et al., 2010). The occurrence of citronellol in mango wines but not in mango juice suggests that it was produced by yeasts during fermentation, likely as a result of hydrolysis of glycosides with bound citronellol as the algycone (Ugliano et al., 2006).

Esters are quantitatively the second largest group in the volatile profiles of the three fermented mango wines (over $25 \%$ RPA), including acetates, methyl esters, ethyl esters and other medium or long-chain esters.

According to RPA, the most significant acetates were ethyl acetate, isoamyl acetate and 2-phenylethyl acetate (Table 3). They showed similar modes of kinetic changes - reaching their maximum on day 4 and decreasing steadily thereafter (Fig. 2). The mango wine fermented with strain MERIT.ferm had higher 
TABLE 3

Major volatile compounds (GC-FID peak area $\times 10^{6}$ ) and their relative peak areas (RPA) in mango wine (day 14$)$ fermented by three $S$. cerevisiae yeasts.

\begin{tabular}{|c|c|c|c|c|c|c|c|c|c|c|}
\hline \multirow[b]{2}{*}{ Groups } & \multirow[b]{2}{*}{ Compounds } & \multirow[b]{2}{*}{ LRI } & \multirow[b]{2}{*}{ CAS. No } & \multicolumn{2}{|l|}{ MERIT.ferm } & \multicolumn{2}{|l|}{ CICC1028 } & \multicolumn{2}{|l|}{ EC1118 } & \multirow{2}{*}{$\begin{array}{l}\text { Aroma descriptors of } \\
\text { pure compounds }^{(1)}\end{array}$} \\
\hline & & & & Peak area & $\begin{array}{l}\text { RPA } \\
(\%)\end{array}$ & Peak area & $\begin{array}{l}\text { RPA } \\
(\%)\end{array}$ & Peak area & RPA $(\%)$ & \\
\hline \multirow[t]{4}{*}{ Acids } & Acetic acid & 1549 & 000064-19-7 & $9.65 \pm 0.14^{a}$ & 0.118 & $3.01 \pm 0.05^{b}$ & 0.035 & $7.82 \pm 0.7^{c}$ & 0.102 & Acidic, vinegar \\
\hline & Octanoic acid & 2170 & $000124-07-2$ & $48.80 \pm 1.4^{a}$ & 0.605 & $65.1 \pm 5.48^{b}$ & 0.817 & $45.60 \pm 0.13^{a}$ & 0.57 & Fatty, soapy, fruity, sour \\
\hline & Decanoic acid & 2390 & $000334-48-5$ & $51.20 \pm 0.856^{a}$ & 0.635 & $75.21 \pm 4.39^{b}$ & 0.944 & $48.77 \pm 2.67^{a}$ & 0.635 & Fatty, rancid, sour \\
\hline & Dodecanoic acid & 2607 & 000143-07-7 & $6.26 \pm 0.40^{a}$ & 0.078 & $11.31 \pm 0.70^{b}$ & 0.142 & $6.39 \pm 0.20^{a}$ & 0.083 & Coconut, fatty \\
\hline Subtotal & & & & 111.91 & 1.436 & 154.43 & 1.938 & 105.2 & 1.37 & \\
\hline \multirow[t]{7}{*}{ Alcohol } & Ethanol & 1028 & $000064-17-5$ & $5330 \pm 109^{a}$ & 66.08 & $4650 \pm 347^{b}$ & 58.34 & $5270 \pm 208^{b}$ & 69.57 & Alcoholic \\
\hline & Isobutyl alcohol & 1172 & $000078-83-1$ & $26.10 \pm 0.52^{a}$ & 0.324 & $20.5 \pm 1.98^{b}$ & 0.257 & $17.80 \pm 0.52^{c}$ & 0.232 & Fruity, wine-like \\
\hline & Isoamyl alcohol & 1237 & $000123-51-3$ & $201 \pm 8.23^{a}$ & 2.492 & $129 \pm 16.4^{b}$ & 1.619 & $120 \pm 3.34^{b}$ & 1.564 & Alcoholic, fruity, banana \\
\hline & Cis-3-hexenol & 1475 & $000928-96-1$ & $2.06 \pm 0.12^{a}$ & 0.026 & $2.14 \pm 0.13^{a}$ & 0.027 & $2.76 \pm 0.12^{b}$ & 0.036 & Green, leafy \\
\hline & 1-Octanol & 1650 & $000111-87-5$ & $0.82 \pm 0.12^{a}$ & 0.01 & $0.28 \pm 0.04^{b}$ & 0.004 & $0.40 \pm 0.05^{b}$ & 0.005 & Fatty, orange -like, citrus \\
\hline & Citronellol & 1867 & $000106-22-9$ & $1.82 \pm 0.16^{a}$ & 0.023 & $1.02 \pm 0.05^{b}$ & 0.013 & $2.63 \pm 0.48^{a}$ & 0.034 & Floral, rose, citrus, green \\
\hline & $\begin{array}{l}\text { 2-Phenylethyl } \\
\text { alcohol }\end{array}$ & 1964 & $000060-12-8$ & $118 \pm 6.91^{a}$ & 1.463 & $48.50 \pm 4.45^{b}$ & 0.609 & $64.70 \pm 3.84^{c}$ & 0.843 & Sweet, rose, floral \\
\hline Subtotal & & & & 5679.8 & 70.418 & 4851.44 & 60.869 & 5578.29 & 72.684 & \\
\hline \multirow[t]{23}{*}{ Esters } & Ethyl acetate & 1009 & $000141-78-6$ & $7.46 \pm 0.24^{a}$ & 0.09 & $5.73 \pm 0.37^{b}$ & 0.071 & $6.18 \pm 0.73^{b}$ & 0.081 & Ethereal, fruity, sweet \\
\hline & Isoamyl acetate & 1112 & $000123-92-2$ & $5.94 \pm 0.40^{a}$ & 0.074 & $1.12 \pm 0.40^{b}$ & 0.014 & $3.19 \pm 0.24^{c}$ & 0.042 & Fruity, banana, pear \\
\hline & n-Octyl acetate & 1576 & $000112-14-1$ & $0.99 \pm 0.07^{a}$ & 0.012 & $0.81 \pm 0.04^{b}$ & 0.01 & $0.80 \pm 0.06^{b}$ & 0.01 & Floral, orange, jasmine-like \\
\hline & Decyl acetate & 1778 & $000112-17-4$ & $1.95 \pm 0.25^{a}$ & 0.024 & $1.93 \pm 0.15^{a}$ & 0.024 & $1.64 \pm 0.16^{a}$ & 0.021 & Fatty, waxy, soapy, fruity \\
\hline & $\begin{array}{l}\text { 2-Phenylethyl } \\
\text { acetate }\end{array}$ & 1862 & $000103-45-7$ & $31 \pm 0.91^{a}$ & 0.384 & $19.3 \pm 0.41^{b}$ & 0.242 & $12.5 \pm 0.32^{c}$ & 0.163 & Floral, rose, sweet \\
\hline & Ethyl hexanoate & 1297 & $000123-66-0$ & $10.31 \pm 1.59^{a}$ & 0.127 & $11.72 \pm 1.23^{a}$ & 0.147 & $9.69 \pm 1.93^{a}$ & 0.126 & Banana, fruity, floral \\
\hline & Ethyl octanoate & 1453 & $000106-32-1$ & $278 \pm 2.87^{a}$ & 3.446 & $298 \pm 6.35^{b}$ & 3.733 & $254 \pm 18.7^{a}$ & 3.31 & Soapy, brandy, apple \\
\hline & Ethyl nonanoate & 1624 & $000123-29-5$ & $0.58 \pm 0.01^{a}$ & 0.007 & $0.44 \pm 0.04^{b}$ & 0.006 & $0.48 \pm 0.01^{b}$ & 0.006 & Fruity, nutty, waxy \\
\hline & Ethyl decanoate & 1746 & $000110-38-3$ & $1400 \pm 52.88^{a}$ & 17.36 & $1910 \pm 170^{b}$ & 23.96 & $1360 \pm 40.11^{a}$ & 17.72 & Waxy, sweet, apple \\
\hline & Ethyl dodecanoate & 1887 & $000106-33-2$ & $370 \pm 12.77^{a}$ & 4.587 & $553 \pm 102^{b}$ & 6.938 & $239 \pm 11.2^{c}$ & 3.114 & Soapy, waxy, floral \\
\hline & Ethyl tetradecanoate & 2161 & 000124-06-1 & $11.90 \pm 1.86^{a}$ & 0.148 & $17.80 \pm 1.15^{b}$ & 0.223 & $8.46 \pm 0.20^{c}$ & 0.11 & -- \\
\hline & Ethyl hexadecanoate & 2373 & $000628-97-7$ & $20.80 \pm 0.34^{a}$ & 0.258 & $15.60 \pm 0.34^{b}$ & 0.196 & $11.00 \pm 0.80^{c}$ & 0.143 & -- \\
\hline & $\begin{array}{l}\text { Ethyl } \\
\text { 9-hexadecenoate }\end{array}$ & 2402 & $054546-22-4$ & $24.50 \pm 2.94^{a}$ & 0.304 & $15.30 \pm 2.01^{b}$ & 0.192 & $8.65 \pm 1.05^{c}$ & 0.113 & -- \\
\hline & Methyl octanoate & 1470 & $000111-11-5$ & $0.40 \pm 0.02^{a}$ & 0.005 & $0.51 \pm 0.01^{b}$ & 0.006 & $0.35 \pm 0.01^{c}$ & 0.005 & Fruity, orange-like \\
\hline & Methyl decanoate & 1687 & $000110-42-9$ & $2.18 \pm 0.12^{a}$ & 0.027 & $3.25 \pm 0.09^{b}$ & 0.041 & $1.94 \pm 0.04^{c}$ & 0.025 & Oily, fruity, wine-like \\
\hline & Methyl dodecanoate & 1907 & $000111-82-0$ & $0.86 \pm 0.14^{a}$ & 0.011 & $1.67 \pm 0.14^{b}$ & 0.021 & $0.63 \pm 0.02^{a}$ & 0.008 & Waxy, soapy, creamy \\
\hline & Isobutyl octanoate & 1642 & $005461-06-3$ & $5.82 \pm 0.13^{a}$ & 0.072 & $7.08 \pm 0.30^{b}$ & 0.089 & $4.24 \pm 0.18^{c}$ & 0.055 & Fruity, green, oily \\
\hline & Isobutyl decanoate & 1859 & $030673-38-2$ & $12.34 \pm 1.06^{a}$ & 0.153 & $16.43 \pm 0.56^{b}$ & 0.206 & $8.01 \pm 0.38^{c}$ & 0.104 & Oily, brandy, apricot \\
\hline & $\begin{array}{l}\text { Isobutyl } \\
\text { dodecanoate }\end{array}$ & 2068 & $037811-72-6$ & $1.24 \pm 0.21^{a}$ & 0.015 & $2.04 \pm 0.13^{b}$ & 0.026 & $0.68 \pm 0.06^{c}$ & 0.009 & Oily, floral, waxy \\
\hline & Isoamyl hexanoate & 1543 & 002198-61-0 & $1.93 \pm 0.04^{a}$ & 0.024 & $1.77 \pm 0.16^{a}$ & 0.022 & $1.33 \pm 0.02^{b}$ & 0.017 & Apple, pineapple, sweet \\
\hline & Isoamyl octanoate & 1762 & $002035-99-6$ & $42.82 \pm 1.09^{a}$ & 0.531 & $45.82 \pm 1.72^{a}$ & 0.575 & $31.68 \pm 1.54^{b}$ & 0.413 & Fruity, sweet, waxy \\
\hline & Isoamyl decanoate & 1973 & 002306-91-4 & $35.95 \pm 1.31^{a}$ & 0.446 & $40.61 \pm 2.69^{b}$ & 0.51 & $20.97 \pm 0.56^{c}$ & 0.273 & Brandy, rum, coconut \\
\hline & $\begin{array}{l}\text { Isoamyl } \\
\text { dodecanoate }\end{array}$ & 2180 & $006309-51-9$ & $3.91 \pm 0.13^{a}$ & 0.048 & $3.95 \pm 0.02^{a}$ & 0.05 & $1.50 \pm 0.03^{b}$ & 0.02 & Mild, waxy, peach \\
\hline Subtotal & & & & 2270.21 & 28.147 & 2959.34 & 37.1 & 1985.92 & 25.877 & \\
\hline
\end{tabular}


TABLE 3 (CONTINUED)

Major volatile compounds (GC-FID peak area $\times 10^{6}$ ) and their relative peak areas (RPA) in mango wine (day 14$)$ fermented by three $S$. cerevisiae yeasts.

\begin{tabular}{|c|c|c|c|c|c|c|c|c|c|c|}
\hline \multirow[b]{2}{*}{ Groups } & \multirow[b]{2}{*}{ Compounds } & \multirow[b]{2}{*}{ LRI } & \multirow[b]{2}{*}{ CAS. No } & \multicolumn{2}{|l|}{ MERIT.ferm } & \multicolumn{2}{|l|}{ CICC1028 } & \multicolumn{2}{|l|}{ EC1118 } & \multirow{2}{*}{$\begin{array}{l}\text { Aroma descriptors of } \\
\text { pure compounds }^{(1)}\end{array}$} \\
\hline & & & & Peak area & $\begin{array}{l}\text { RPA } \\
(\%)\end{array}$ & Peak area & $\begin{array}{l}\text { RPA } \\
(\%)\end{array}$ & Peak area & RPA (\%) & \\
\hline \multirow[t]{5}{*}{ Ketones } & Acetoin & 1401 & $000513-86-0$ & $0.12 \pm 0.01^{a}$ & 0.001 & $0.02 \pm 0.00^{b}$ & 0 & $0.36 \pm 0.04^{c}$ & 0.005 & Butter-like \\
\hline & 2-Undecanone & 1695 & $000112-12-9$ & $0.09 \pm 0.02^{a}$ & 0.001 & $0.80 \pm 0.04^{b}$ & 0.01 & $1.35 \pm 0.09^{c}$ & 0.017 & Rose, citrus, orris-like \\
\hline & $\begin{array}{l}\text { 1-(4-Methylphenyl)- } \\
\text { ethanone }\end{array}$ & 1903 & $000122-00-9$ & $0.17 \pm 0.02^{a}$ & 0.002 & $0.21 \pm 0.00^{b}$ & 0.003 & $0.18 \pm 0.00^{a}$ & 0.002 & Floral \\
\hline & Beta-damascenone & 1938 & $023696-85-7$ & $0.44 \pm 0.00^{a}$ & 0.005 & $0.56 \pm 0.02^{b}$ & 0.007 & $0.38 \pm 0.02^{c}$ & 0.005 & Berry, woody, floral \\
\hline & Gamma-decalactone & 2281 & 000706-14-9 & $0.16 \pm 0.02^{a}$ & 0.002 & $0.16 \pm 0.00^{a}$ & 0.002 & $0.17 \pm 0.02^{a}$ & 0.002 & Creamy, fruity, peach \\
\hline Subtotal & & & & 0.98 & 0.011 & 1.75 & 0.022 & 2.44 & $\mathbf{0 . 0 3 1}$ & \\
\hline \multirow[t]{3}{*}{ Aldehydes } & Acetaldehyde & 939 & $000075-07-0$ & $5.20 \pm 0.32^{a}$ & 0.064 & $2.60 \pm 1.04^{b}$ & 0.032 & $6.01 \pm 1.91^{a}$ & 0.078 & Pungent, green \\
\hline & Benzaldehyde & 1637 & $000100-52-7$ & $0.31 \pm 0.02^{a}$ & 0.004 & $0.28 \pm 0.00^{a}$ & 0.004 & $0.23 \pm 0.02^{b}$ & 0.003 & Bitter almond \\
\hline & $p$-Tolualdehyde & 1773 & 000104-87-0 & $1.38 \pm 0.16^{a}$ & 0.017 & $2.92 \pm 0.16^{b}$ & 0.037 & $1.33 \pm 0.09^{a}$ & 0.017 & Cherry, sweet \\
\hline Subtotal & & & & 6.89 & 0.085 & 5.8 & 0.073 & 7.57 & 0.098 & \\
\hline Miscellaneous & $\begin{array}{l}\text { Dihydro-2-methyl- } \\
3(2 \mathrm{H}) \text {-thiophenone }\end{array}$ & 1637 & $013679-85-1$ & $0.58 \pm 0.13^{a}$ & 0.007 & $0.59 \pm 0.02^{a}$ & 0.007 & $0.48 \pm 0.02^{b}$ & 0.006 & Sulfur, fruity, berry \\
\hline Subtotal & & & & 0.58 & 0.007 & 0.59 & 0.007 & 0.48 & 0.006 & \\
\hline Total & & & & 8510.37 & & 7973.35 & & 7579.9 & & \\
\hline
\end{tabular}

${ }^{a b c}$ ANOVA $(n=4)$ at $95 \%$ confidence level with same letters indicating no significant difference.

(1) Descriptors were retrieved from http://www.thegoodscentscompany.com.

concentrations of acetate esters than the other two (Table 4). Acetates are produced from the reaction of acetyl-CoA with alcohols (Perestrelo et al., 2006) and thus, the higher production of acetates by strain MERIT.ferm-fermented wine may be due to the higher quantities of ethanol and branched-chain higher alcohols that strain MERIT.ferm produced (i.e. increased substrate availability). Additionally, the concentrations of 2-phenylethyl acetate and isoamyl acetate for all three wines were higher than their threshold levels for all three wines (Table 4), but ethyl acetate was slightly lower than its threshold level (Table 4). The esters of this group have a positive contribution to the overall quality of the wine and most produce moderate "floral" or "fruity" flavours (Table 3)

Ethyl esters are produced enzymatically during the synthesis or degradation of fatty acids (Alves et al., 2010). The concentration of these esters is dependent on several factors, including: yeast strain, fermentation temperature, aeration and sugar content (Perestrelo et al., 2006). Ethyl esters can add moderate notes of ripe fruits to fermented wine if they are in the desirable range (Alves et al., 2010). The major ethyl esters in our fermented wines were ethyl octanoate, ethyl decanoate and ethyl dodecanoate (Table 3), and the concentrations of these esters were higher than their threshold levels for all three wines (Table 4). The kinetic changes of the three esters are shown in Fig. 3. In addition, strain CICC1028-fermented wine had significantly higher concentrations of the three ethyl esters than the other two wines, which could be linked to its high production of medium-chain fatty acids (Table 4). This is supported by a recent study that demonstrates the crucial role of the fatty acid precursor level in ethyl ester production by $S$. cerevisiae (Saerens et al., 2008).

Other esters, such as ethyl hexanoate, isobutyl octanoate, isoamyl hexanoate, isoamyl octanoate, were also identified in mango wines (Table 3). Strains CICC1028 and MERIT.ferm were better at producing these esters than strain EC1118.

Acetic, octanoic, decanoic and dodecanoic acids were the major fatty acids detected in mango wines. Acetic acid was highest in the MERIT.ferm-fermented wine, and it reached 0.034, 0.01, 0.025 g/100 mL for strains MERIT.ferm, CICC1028 and EC1118 on day 14, respectively (Table 4). The kinetic change of acetic acid is shown in Fig. 4. Acetic acid in high concentrations is undesirable in alcoholic beverages, which may impart a vinegar off-odor. Acetic acid in the MERIT.ferm and EC1118 fermented mango wine was slightly higher than the threshold level (Table 4), but whether this would affect wine quality needs sensory evaluation. In the study of Lambrechts and Pretorius (2000), acetic acid between $0.02-0.07 \mathrm{~g} / 100 \mathrm{~mL}$ was considered optimal depending on the style of wine, therefore, acetic acid in Merit.ferm and EC1118 fermented mango wine may not bring about a negative flavour note. In addition, strain CICC1028 produced the highest levels of medium-chain fatty acids such as octanoic acid, decanoic acid and dodecanoic acid (Table 3). The kinetic change of octanoic acid is shown in Fig. 1, and it increased initially, and then decreased slightly and remained constant after day 6. Decanoic and dodecanoic acids showed similar kinetic changes to those of octanoic acid (data not shown). The concentration of octanoic acid was also quantified in Table 4, and it was just at the threshold level for the three wines. These medium-chain fatty acids may impart fatty, rancid and soapy off-odours, so they must be controlled 

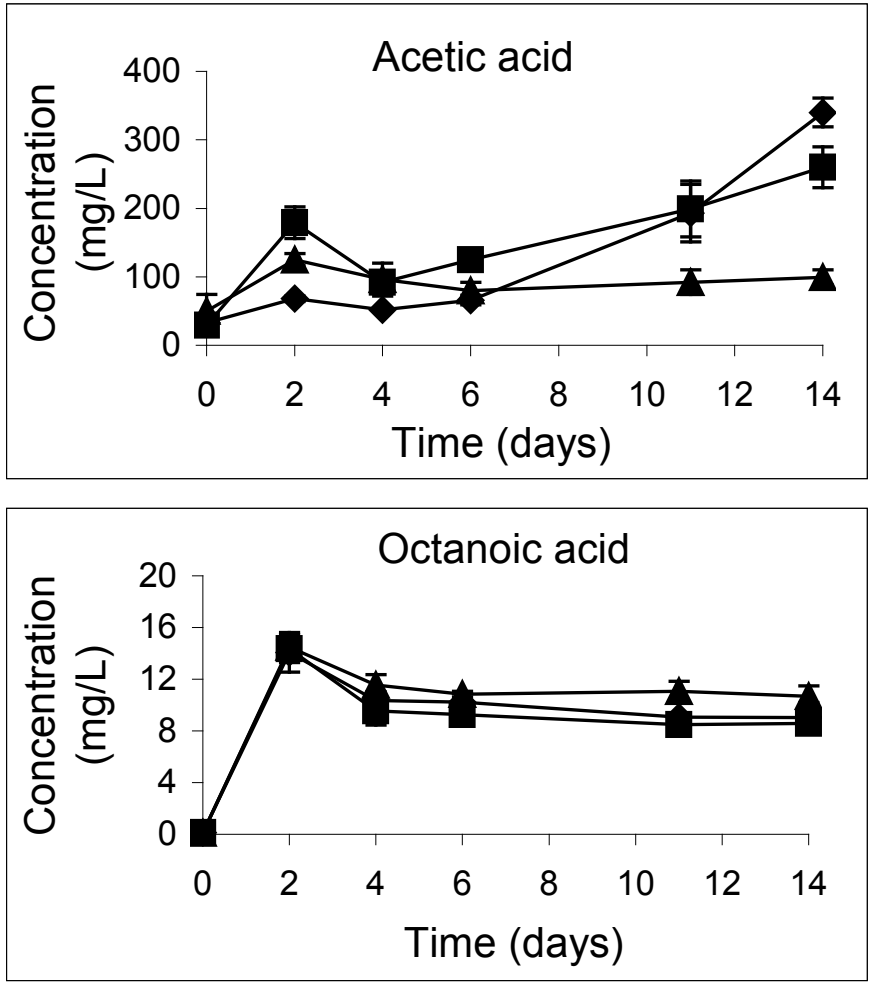

FIGURE 4

Changes of fatty acids in mango wines during fermentation by S. cerevisiae MERIT.ferm ( ), S. chevalieri CICC-1028 ( $\Delta$ ) and $S$. bayanus EC-1118( $\mathbf{(})$. at low levels or at least not higher than their threshold levels. Furthermore, they could also act as potential inhibitors of alcoholic fermentation (Lambrechts \& Pretorius, 2000). This may explain why the cell count of strain CICC1028 was 10 times lower than those of strains Merit.ferm and EC1118.

Acetaldehyde, benzaldehyde, $p$-tolualdehyde were identified in mango wines and acetaldehyde was the major aldehyde (Table 3). Compared with other volatiles, aldehydes were only a minor group with less than $0.1 \%$ RPA. At low levels, acetaldehyde gives a pleasant fruity aroma to wines, but in higher concentrations, it has a pungent, irritating odor (Miyake \& Shibamoto, 1993). In addition, acetaldehyde originated as an intermediary product of yeast metabolism from pyruvate through the glycolytic pathway and it is also a precursor for acetate, acetoin as well as ethanol (Collins, 1972).

Five ketones were identified in mango wines. Betadamascenone concentration decreased during fermentation, whereas other ketones such as 2-undecanone, acetoin almost kept constant after day 4 (data not shown). Beta-damascenone was one of a few compounds which were identified in both fresh mango juice and wine. A sulfur ketone [dihydro-2methyl-3(2H)-thiophenone] was found in all three mango wines (Table 3) but not in the fresh mango juice, which was probably produced by yeasts during fermentation. This sulfur compound is usually found in malt whiskey (Masuda \& Nishimura, 1982) and it may contribute to blackberry flavor. This is the first time that dihydro-2-methyl-3(2H)-thiophenone was found in mango wine from the best of our knowledge. Although these ketones

TABLE 4.

Concentrations of selected volatile compounds (mg/L) and the corresponding odor activity values (OAVs) in mango wines fermented with culture of three S. cerevisiae yeasts on Day 14.

\begin{tabular}{|c|c|c|c|c|c|c|c|c|c|}
\hline Compounds & CAS No. & $\begin{array}{l}\text { Retention } \\
\text { index }\end{array}$ & $\begin{array}{l}\text { MERIT.ferm } \\
(\mathrm{mg} / \mathrm{L})\end{array}$ & $\mathrm{OAV}^{(1)}$ & $\begin{array}{c}\mathrm{CICC} 1028 \\
(\mathrm{mg} / \mathrm{L})\end{array}$ & OAV & $\begin{array}{c}\mathrm{EC} 1118 \\
(\mathrm{mg} / \mathrm{L})\end{array}$ & OAV & $\begin{array}{l}\text { Odor threshold } \\
(\mathrm{mg} / \mathrm{L})\end{array}$ \\
\hline Ethyl acetate & 000141-78-6 & 1009 & $1.81 \pm 0.23^{a}$ & 0.24 & $1.16 \pm 0.08^{b}$ & 0.15 & $1.25 \pm 0.11^{b}$ & 0.17 & $7.5^{(2)}$ \\
\hline Ethanol & 000064-17-5 & 1028 & $70136 \pm 1080^{a}$ & -- & $61543 \pm 663^{b}$ & -- & $63027 \pm 464^{b}$ & -- & Not applicable \\
\hline Isobutyl alcohol & 000078-83-1 & 1097 & $22.20 \pm 2.60^{a}$ & 0.56 & $14.72 \pm 2.54^{b}$ & 0.37 & $9.43 \pm 0.83^{c}$ & 0.24 & $40^{(2)}$ \\
\hline Isoamyl acetate & 000123-92-2 & 1112 & $0.35 \pm 0.03^{a}$ & 11.67 & $0.04 \pm 0.02^{b}$ & 1.33 & $0.12 \pm 0.01^{c}$ & 4 & $0.03^{(2)}$ \\
\hline Isoamyl alcohol & $000123-51-3$ & 1237 & $409.85 \pm 42.66^{a}$ & 13.67 & $146.43 \pm 6.71^{b}$ & 4.88 & $136.91 \pm 23.18^{b}$ & 4.56 & $300^{(2)}$ \\
\hline Ethyl octanoate & 000106-32-1 & 1453 & $10.06 \pm 0.31^{a}$ & 5030 & $10.88 \pm 0.10^{b}$ & 5440 & $9.27 \pm 0.68^{a}$ & 4635 & $0.002^{(2)}$ \\
\hline Acetic acid & 000064-19-7 & 1549 & $340 \pm 21^{a}$ & 1.7 & $99 \pm 11^{b}$ & 0.5 & $260 \pm 30^{c}$ & 1.3 & $200^{(2)}$ \\
\hline Ethyl decanoate & 000110-38-3 & 1746 & $12.56 \pm 0.06^{a}$ & 62.80 & $16.07 \pm 2.06^{b}$ & 80.35 & $11.85 \pm 0.31^{a}$ & 59.25 & $0.2^{(3)}$ \\
\hline $\begin{array}{l}\text { 2-Phenylethyl } \\
\text { acetate }\end{array}$ & 000103-45-7 & 1862 & $1.17 \pm 0.06^{a}$ & 4.68 & $0.75 \pm 0.05^{b}$ & 3 & $0.45 \pm 0.01^{c}$ & 1.8 & $0.25^{(2)}$ \\
\hline Ethyl dodecanoate & 000106-33-2 & 1887 & $11.32 \pm 0.51^{a}$ & 9.43 & $18.61 \pm 0.84^{b}$ & 15.51 & $7.60 \pm 1.92^{c}$ & 6.33 & $1.2^{(3)}$ \\
\hline $\begin{array}{l}\text { 2-Phenylethyl } \\
\text { alcohol }\end{array}$ & $000060-12-8$ & 1964 & $59.56 \pm 1.30^{a}$ & 5.96 & $13.27 \pm 2.19^{b}$ & 2.45 & $27.72 \pm 0.69^{c}$ & 2.77 & $10^{(2)}$ \\
\hline Octanoic acid & 000124-07-2 & 2100 & $9.04 \pm 1.16^{a}$ & 1.03 & $10.67 \pm 0.81^{b}$ & 1.21 & $8.58 \pm 0.41^{a}$ & 0.975 & $8.8^{(3)}$ \\
\hline
\end{tabular}

${ }^{a b c} \operatorname{ANOVA}(\mathrm{n}=4)$ at $95 \%$ confidence level with the same letters indicating no significant difference.

(1) Odour activity values (OAV) were calculated by dividing concentration by the odour threshold value of the compound.

(2) The odor threshold was obtained from Guth (1997).

(3) The odor threshold was obtained from Bartowsky \& Pretorius (2008). 
had low concentrations, they may contribute to "floral" or "fruity" aroma to mango wines synergistically.

It will be valuable to correlate the data obtained from instrumental analysis with the result of sensory evaluation. It is recognised that sensory analysis was not performed in this study due to a lack of trained panel. Further studies will include sensory evaluation to compare the sensory and chemical profiles of mango wines fermented with different yeasts on a larger-scale.

\section{CONCLUSION}

The presence of volatile compounds and their concentrations during mango juice fermentation were dependent on the yeast strain used as the starter culture. The results obtained by the HS-SPME-GC-MS/FID technique showed differences in the volatile profiles of three mango wines fermented with different $S$. cerevisiae yeast strains. The mango wine from the fermentation with strain MERIT.ferm produced more branchedchain higher alcohols and aromatic branched-chain esters when compared to the other two wines fermented with strains EC1118 and CICC1028, so it can be selected as a good candidate for mixed-culture fermentation with one Williopsis saturnus yeast in subsequent studies.

\section{LITERATURE CITED}

Anonymous,http://www.liancome.com/liancome_mango.htm.

Anonymous, http://www.thegoodscentscompany.com

Alves, J. A., Lima, L. C. O, Dias, D. R., Nunes, C. A. \& Schwan, R. F., 2010. Effects of spontaneous and inoculated fermentation on the volatile profile of lychee (Litchi chinensis Sonn) fermented beverages. Int. J. Food Sci. Tech. 45, 2358-2365

Bartowsky, E. J. \& Pretorius, I. S., 2008. Microbial formation and modification of flavor and off-flavor compounds in wine. In: König, H., Uden, G. \& Frohlich, J. (eds). Biology of microorganisms on grapes, in must and in wine. SpringerVerlag, Berlin. pp 215-217.

Chávez-Servín, J. L., Castellote, A. I. \& López-Sabater, M. C., 2004. Analysis of mono- and disaccharides in milk-based formulae by high-performance liquid chromatography with refractive index detection. J. Chromatogr. A. 1043, 211 215 .

Collins, E. B., 1972. Biosynthesis of flavor compounds by microorganisms. J. Dairy Sci. 55(7), 1022-1028.

Coloretti, F., Zambonelli, C., Castellari, L., Tini, V. \& Rainieri, S., 2002. The effect of DL-malic acid on the metabolism of L-malic acid during wine alcoholic fermentation. Food Technol. Biotech. 40(4), 317-320.

Czyhrinciwk, N., 1966. The technology of passion fruit and mango wines. Am. J. Enol. Viticult. 17, 27-30.

Dickinson, J. R., Harrison, S. J. \& Michael, J. E., 1998. An investigation of the metabolism of valine to isobutyl alcohol in Saccharomyces cerevisiae. J. Biol. Chem. 273(40), 25751-25756.

Etschmann, M., Bluemke, W., Sell, D. \& Schrader, J., 2002. Biotechnological production of 2-phenylethanol. Appl. Microbiol. Biot. 59(1), 1-8.

Gürbüz, O., Rouseff, J. M. \& Rouseff, R. L., 2006. Comparison of aroma volatiles in commercial Merlot and Cabernet Sauvignon wines using gas chromatography - olfactory and gas chromatography - mass spectrometry. Int. J. Food Sci. Tech. 54, 3990-3396.
Guth, H., 1997. Quantitation and sensory studies of character impact odorants of different white wine varieties. J. Agric. Food Chem. 45, 3027-3032.

Kumar, Y. S., Prakasam, R. S. \& Reddy, O. V. S., 2009. Optimisation of fermentation conditions for mango (Mangifera indica L.) wine production by employing response surface methodology. Int. J. Food Sci. Tech. 44, 23202327.

Lambrechts, M. G. \& Pretorius, I. S. (2000). Yeast and its importance to wine aroma - a review. S. Afr. J. Enol. Vitic. 21, 97-129.

Lee, P. R., Ong, Y. L., Yu, B., Curran, P. \& Liu, S. Q., 2010a. Profile of volatile compounds during papaya juice fermentation by a mixed culture of Saccharomyces

cerevisiae and Williopsis saturnus. Food Microbiol. 22(7), 853-861.

Lee, P. R., Ong, Y. L., Yu, B., Curran, P. \& Liu, S. Q., 2010b. Evolution of volatile

compounds in papaya wine fermented with three Williopsis saturnus yeasts. Int. J. Food Sci. Tech. 45(10), 2032-2041.

Masuda, M. \& Nishimura, K., 1982. Changes in volatile sulfur compounds of whisky during aging. J. Food Sci. 47(1), 101-105.

Miyake, T., \& Shibamoto, T., 1993. Quantitative analysis of acetaldehyde in foods and beverages. J. Agric. Food Chem. 41(11), 1968-1970.

Myers, M. J., Issenberg, P. \& Wick, E. L., 1970. L-leucine as a precursor of isoamyl

alcohol and isoamyl acetate, volatile aroma constituents of banana fruit discs Phytochemistry 9(8), 1693-1700.

Noguerol-Pato, R., González-Barreiro, B., Cancho-Grande, B. \& SimalGándara, B., 2009. Quantitative determination and characterization of the main odorants of

Mencía monovarietal red wines. Food Chem. 117(3), 473-484.

Obisanya, M. O., Aina, J. O. \& Oguntime, G. B., 1987. Production of wine from mango (Magnifera indica L.) using Saccharomyces and Schizosaccharomyces species isolated from palm wine. J. Appl. Bacteriol. 63, 191-196.

Ong, P.K.C. \& Acree, T.E., 1999. Similarities in the aroma chemistry of Gewürztraminer variety wines and lychee (Litchi chinesis Sonn.) fruit. J. Agric. Food Chem.47, 665-670.

Onkarayya, H. \& Singh, H.,1984. Screening of mango varieties for dessert and mandeira-style wine. Am. J. Enol.Viticult. 35, 63-65.

Perestrelo, R., Fernandes, A., Albuquerque, F., Marques, J. \& Camara, J., 2006. Analytical characterization of the aroma of Tinta Negra Mole red wine: identification of the main odorants compounds. Anal. Chim. Acta 563(1-2), 154-164.

Pino, J. A., \& Mesa, J., 2005. Contribution of volatile compounds to mango (Mangifera indica L.) aroma. Flavour Frag. J. 21, 207-213.

Pino, J. A., Mesa, J., Munoz, Y., Marti, M. P. \& Marbot, R., 2005. Volatile components from mango (Mangifera indica L.) cultivars. J. Agric. Food Chem. $53,2213-2223$.

Rapp, A. \& Mandery, H., 1986. Wine aroma. Experientia 42, 873-884.

Rapp, A. \& Mandery, H., 1987. New progress in wine and wine research Experientia 45, 873-884.

Rapp, A., 1988. Wine aroma substances from gas chromatographic analysis. In: Liskens, H. \& Jackson, J. (eds). Modern methods of plant analysis. SpringerVerlag, Berlin. pp. 29-65.

Reddy, L. V. A. \& Reddy, O. V. S., 2005. Production and characterization of wine from mango fruit (Mangifera indica L). World J. Microb. Biot. 21, 13451350 . 
Reddy, L. V. A. \& Reddy, O. V. S., 2009. Effect of enzyme maceration on synthesis of higher alcohols during mango wine fermentation. J. Food Quality $32,34-47$.

Saerens, S. M. G., Delvaux, F., Verstrepen, K. J., van Dijck, P., Thevelein, J. M. \& Delvaux, F.R., 2008. Parameters affecting ethyl ester production by Saccharomyces cerevisiae during fermentation. Appl. Environ. Microbiol. 74(2):454-461.

Spreer, W., Ongprasert, S., Hegele, M., Wunsche, J. N. \& Muller, J., 2009. Yield and fruit development in mango (Mangifera indica L. cv. Chok Anan) under different irrigation regimes. Agr. Water Manage. 96, 574-584.

Tairu, A. O., Hofmann, T. \& Schieberle, P., 1999. Characterization of the key aroma compounds in dried fruits of the west african peppertree Xylopia aethiopica (Dunal) A. Rich (Annonaceae) using aroma extract dilution analysis. J. Agri. Food Chem. 47, 3285-3287.

Tharanathan, R. N., Yashoda, H. M. \& Prabha, T. N., 2006. Mango (Mangifera indica L.), "the king of fruits"- an overview. Food Rev. Int. 22, 95-123.
Trinh, T. T. T., Woon, W. Y., Yu, B., Curran, P. \& Liu, S. Q., 2010. Effect of L-isoleucine and L-phenylalanine addition on aroma compound formation during longan juice fermentation by a co-culture of Saccharomyces cerevisiae and Williopsis saturnus. S. Afr. J. Enol. Vitic. 31(2), 116-124.

Ugliano, M., Bartowsky, E.J., McCarthy, J., Moio, L. \& Henschke, P.A., 2006 Hydrolysis and transformation of grape glycosidically bound volatile compounds during fermentation with three Saccharomyces yeast strains. J. Agric. Food Chem. 54, 6322-6331.

Yilmaztekin, M., Erten, H. \& Cabaroglu, T., 2009. Enhanced production of isoamyl acetate from beet molasses with addition of fusel oil by Williopsis saturnus var. saturnus. Food Chem. 112, 290-294.

Zoecklein, B. W., Marcy, J. E., Williams, J. M. \& Jasinski, Y., 1997. Effect of native yeasts and selected strains of Saccharomyces cerevisiae on glycosyl glucose, potential volatile terpenes, and selected aglycones of white Riesling (Vitis vinifera L.) wines. J. Food Compos. Anal. 10, 55-65. 